\title{
Reductively debrominating strains of Propionigenium maris from burrows of bromophenol-producing marine infauna
}

\author{
Jamey Watson ,' George Y. Matsui,, ${ }^{1}$ Adam Leaphart, ${ }^{1}$ Juergen Wiegel, ${ }^{2}$ \\ Frederick A. Rainey ${ }^{3}$ and Charles R. Lovell ${ }^{1}$
}

1 Department of Biological Sciences, University of South Carolina, Columbia, SC 29208, USA

2 Department of Microbiology, University of Georgia, Athens, GA 30602, USA

3 Department of Biological Sciences, Louisiana State University, Baton Rouge, LA 70808, USA

\author{
Author for correspondence: Charles R. Lovell. Tel: +1 803777 7036. Fax: +1 8037774002. \\ e-mail: lovell@biol.sc.edu
}

\begin{abstract}
Two novel strains of Propionigenium maris able to reductively debrominate 2,4,6-tribromophenol (TBP) to monobromophenols were isolated from marine hemichordate and polychaete burrows. These two strains, DSL-1 and ML-1, were anaerobic, non-motile rods that stained Gram-negative and required $0.05 \%$ yeast extract for growth. Strain DSL-1 fermented pyruvate and succinate to predominantly butyrate and strain ML-1 fermented glucose and succinate primarily to propionate. No inorganic terminal electron acceptors were identified. The $\mathrm{pH}$ and temperature optima for growth were 7.6 and $30^{\circ} \mathrm{C}$ for strain DSL- 1 and 7.0 and $32{ }^{\circ} \mathrm{C}$ for strain ML-1, respectively; doubling times for strains DSL-1 and ML-1 were $0.32 \mathrm{~h}$ and $0.30 \mathrm{~h}$, respectively. Both strains required 2-3\% (w/v) $\mathrm{NaCl}$ for optimal growth. Morphological and physiological features, as well as the results of 16S rDNA sequence analysis, showed these to be new strains of Propionigenium maris. Because they differ from the $P$. maris type strain (DSM $9537^{\top}$ ) in a number of respects, including their ability to rapidly debrominate di- and tribromophenols, and in their specific habitats, the species description is amended to include these ecologically important properties.
\end{abstract}

Keywords: reductive dehalogenation, bromophenols, marine sediments, infaunal burrows, Propionigenium

\section{INTRODUCTION}

Biogenic bromoaromatic compounds are broadly distributed in intertidal marine sediments (King, 1986; D. E. Lincoln, K. T. Fielman, R. L. Marinelli and S. A. Woodin, unpublished data; Steward et al., 1992; Woodin et al., 1987). A variety of infaunal hemichordate and polychaete worms produce bromoaromatic compounds including, but not limited to, bromophenols, bromopyrroles, bromoindoles and bromobenzylalcohols (Fielman et al., 1999; Woodin et al., 1987). These bromometabolites are produced through the action of haloperoxidases (Chen et al., 1991) and reach very high levels in the worm tissues (Fielman \& Targett, 1995; Yoon et al., 1994). The highest concentrations of bromometabolites external

Abbreviations: DBP, 2,4-dibromophenol; LPS, lipopolysaccharide; TBP, 2,4,6-tribromophenol.

The EMBL accession numbers for the 165 rDNA sequences of strains DSL-1 and ML-1 are Y16799 and Y16800, respectively. to the animals are found in sediments lining the animals' burrows (King, 1986; D. E. Lincoln, K. T. Fielman, R. L. Marinelli and S. A. Woodin, unpublished data). Turnover of bromophenols in shallow marine sediments can be rapid (Steward \& Lovell, 1997) and the burrow linings, due to the abundance of carbon co-substrates and potential electron acceptors and high levels of bacterial biomass (Steward et al., 1996; Phillips \& Lovell, 1999), are expected to be sites of enhanced debromination and degradation of bromoaromatic compounds. The microbiota inhabiting these burrow lining biofilms are thus of considerable interest for detailed studies of debromination processes. Presently little is known about the diversity of species carrying out reductive dehalogenation processes in marine systems.

The large extent of contaminated sediments and the diversity of microenvironments available in coastal marine systems implies the existence of a plethora of haloaromatic dehalogenating and/or degrading species there. However, although mixed culture and 
sediment slurry studies of marine haloaromatic dehalogenation and degradation are abundantly documented in the literature (e.g. Abrahamsson \& Klick, 1991; Allard et al., 1991; Boothe et al., 1997; Genthner et al., 1989; Häggblom \&Young, 1990, 1995; King, 1988; Monserrate \& Häggblom, 1997; Remberger et al., 1986) and dehalogenating bacteria from freshwater and terrestrial environments have been intensively studied (see El Fantroussi et al., 1998; Fetzner \& Lingens, 1994; Häggblom, 1992; Hale et al., 1994; Janssen et al., 1994; Mohn \& Tiedje, 1992 for recent reviews), marine strains highly active against multiply substituted haloaromatics have proven difficult to enrich and isolate into pure culture. This is particularly true of reductively dehalogenating organisms, which can remove halogen atoms from the aromatic ring. This process is crucial in the consortial degradation of multiply substituted haloaromatics since compounds with few substituent halogen atoms, particularly monohalogenated aromatics, are mineralized much more readily than multiply substituted compounds with the same aromatic ring structure (Neilson, 1990). No pure culture able to dechlorinate multiply chlorinated chloroaromatic compounds has been reported from marine systems and only two marine strains able to debrominate multiply brominated aromatics have been described to date (Boyle et al., 1999; Steward et al., 1995). This limited roster of dehalogenators restricts studies of the physiology and biochemistry of reductive dehalogenation in marine micro-organisms, a reaction catalysed by several classes of enzymes differing in structure and, in some cases, in reaction mechanism (Y. P. Chen, J. Watson and C. R. Lovell, unpublished data; Holliger et al., 1999; Löffler et al., 1996; Ni et al., 1995; Steward et al., 1995). Here, the characterization and phylogenetic affiliation of two reductively debrominating marine anaerobic strains of Propionigenium maris are presented. The description of this species is amended since the two novel strains are capable of rapid reductive debromination of 2,4,6-tribromophenol (TBP) and 2,4-dibromophenol (DBP), producing monobromophenols as terminal products, a property not described for the type strain.

\section{METHODS}

Materials and strains. Bromophenol substrates and standards were obtained from Aldrich and used without further purification. P. maris DSM $9537^{\mathrm{T}}$ was obtained from the Deutsche Sammlung von Mikroorganismen und Zellkulturen $\mathrm{GmbH}$. The isolation of strain DSL-1 has been described elsewhere (Steward et al., 1995). Samples for enrichment of strain ML-1 were collected from the North Inlet salt marsh, Georgetown, South Carolina, USA $\left(30^{\circ} 20^{\prime} \mathrm{N}, 7^{\circ} 10^{\prime} \mathrm{W}\right)$. These samples consisted of burrow linings of the capitellid polychaete Notomastus lobatus, a common inhabitant of clay-rich intertidal mud flats in this system and a well-studied producer of TBP, DBP and 4bromophenol (Chen et al., 1991; Lovell et al., 1999; Steward et al., 1992, 1996; Steward \& Lovell, 1997; Yoon et al., 1994). The burrow scrapings were transported on ice to
Columbia, South Carolina, where enrichment cultures were prepared following previously described methods (Steward et al., 1995). Enrichment media had $\mathrm{pH}$ values of 5.5-7.5 and all contained $1 \mathrm{mM}$ TBP, a concentration comparable to that of total bromophenols in $N$. lobatus burrow linings (D. E. Lincoln, K. T. Fielman, R. L. Marinelli and S. A. Woodin, unpublished data). These enrichment media also contained acetate, lactate, sodium benzoate or succinate (40 mM final concentration) as a supplemental carbon source. The cultures were incubated in the dark at $32^{\circ} \mathrm{C}$. Growth was seen within a few days in all cultures except those containing sodium benzoate. All growing cultures actively debrominated TBP as assessed by GC (Steward et al., 1995). The $\mathrm{pH} 7 \cdot 0$, succinate-supplemented culture had few microscopically distinguishable cell types and was selected for pure culture isolation of debrominators using the agar shake method (Steward et al., 1995). Colonies were visible within 1 week and were aseptically transferred into fresh succinate medium. This process was repeated four times, with each successive culture checked for homogeneity by phase-contrast microscopy. All cultures were homogeneous with respect to cell morphology and were apparently identical to each other. One pure culture from this group was selected arbitrarily and designated strain ML-1.

\section{Growth media}

DSL-1. The growth medium was a minor modification of the medium of Steward et al. (1995) and contained the following $\left(\mathrm{g} \mathrm{l}^{-1}\right): \mathrm{KH}_{2} \mathrm{PO}_{4}, 0 \cdot 2 ; \mathrm{NH}_{4} \mathrm{Cl}, 0 \cdot 3 ; \mathrm{KCl}, 0 \cdot 5 ; \mathrm{CaCl}_{2} .2 \mathrm{H}_{2} \mathrm{O}$, $0 \cdot 15 ; \mathrm{NaCl}, 20 ; \mathrm{MgCl}_{2} \cdot 6 \mathrm{H}_{2} \mathrm{O}, 3.0$; Bacto yeast extract, 0.5 ; SL-9 trace metal solution (Tschech \& Pfennig, 1984), $1 \mathrm{ml} \mathrm{l}^{-1}$. The basal medium was adjusted to $\mathrm{pH} 5 \cdot 5$ and, after autoclaving, the medium was supplemented with sterile filtered $1 \mathrm{mM}$ TBP, autoclaved cysteine sulfide (0.0028\% cysteine, $0 \cdot 0028 \%$ sodium sulfide, $\mathrm{w} / \mathrm{v}$, final concentration), and autoclaved $\mathrm{NaHCO}_{3}$ (50 mM final concentration). In some experiments, a supplemental carbon source (acetate, benzoate, citrate, crotonate, ethanol, fumarate, glucose, lactate, malate, oxalate, propionate, pyruvate or succinate at 4-20 $\mathrm{mM}$ final concentration) and/or potential terminal electron acceptor (nitrate, fumarate and sodium thiosulfate at $5 \mathrm{mM}$ final concentration) were added. Routine cultivation of strain DSL-1 was performed using $20 \mathrm{mM}$ succinate as supplemental carbon source with no added terminal electron acceptor. The complete medium was adjusted to $\mathrm{pH} 7 \cdot 5$.

ML-1. The growth medium for strain ML-1 was derived from the DSL-1 medium recipe, substituting $\operatorname{HEPES}\left(4 \cdot 8 \mathrm{~g} \mathrm{l}^{-1}\right)$ for the carbonate buffer, and adding Bacto Casitone $\left(1.0 \mathrm{~g} \mathrm{l}^{-1}\right)$ as an additional supplement. Routine cultivation employed the ML-1 basal medium supplemented with $40 \mathrm{mM}$ succinate. Culture growth was monitored by direct microscopic counting using a Petroff-Hauser counting chamber.

pH and temperature ranges and $\mathrm{NaCl}$ requirements. The $\mathrm{pH}$ and temperature ranges for growth of strains DSL-1 and ML-1 were determined in triplicate for cultures growing on succinate-supplemented basal media. Optimum $\mathrm{pH}$ and $\mathrm{NaCl}$ requirement determinations were performed at room temperature for strain DSL- 1 and at $32{ }^{\circ} \mathrm{C}$ for strain ML-1. Basal medium $\mathrm{pH}$ values were adjusted to one unit below the desired $\mathrm{pH}$ of the complete medium and the final $\mathrm{pH}$ was checked after addition of TBP, cysteine sulfide and (for the DSL-1 medium) bicarbonate buffer. Addition of these supplements increased the $\mathrm{pH}$ of the media by roughly one unit. When necessary, additional minor adjustments were made using sterile degassed $1 \mathrm{M} \mathrm{NaOH}$ or $1 \mathrm{M} \mathrm{HCl}$. The $\mathrm{pH}$ range tested for strain DSL-1 was 6.5-8.5 and that for strain 
ML-1 was 5.5-7.5. The temperature range for growth of strain DSL-1 was determined at $\mathrm{pH} 7 \cdot 5$ and over $10-50{ }^{\circ} \mathrm{C}$. The temperature range for strain ML-1 was determined at $\mathrm{pH} \mathrm{7.0}$ and temperatures between 20 and $40{ }^{\circ} \mathrm{C}$ were used. Both strains were tested for growth within the ranges specified at $5{ }^{\circ} \mathrm{C}$ temperature intervals. Once the approximate temperature optima were determined, the strains were retested using $2^{\circ} \mathrm{C}$ temperature intervals near the optima. The $\mathrm{NaCl}$ requirement for each organism was determined by varying the $\mathrm{NaCl}$ content of the succinate-supplemented basal medium recipes. The unmodified media both contained $2 \% \mathrm{NaCl}(\mathrm{w} / \mathrm{v})$. Inoculations from these $2 \% \mathrm{NaCl}$ media were into media containing different $\mathrm{NaCl}$ levels $(0-6 \%)$.

Determination of fermentation products. Fermentation products were determined using a Hewlett Packard 1100 series HPLC system equipped with a $25 \mathrm{~cm}$ Microsorb-MV C18 reversed-phase column (Rainin/Varian) and using a $0.005 \mathrm{M} \mathrm{H}_{2} \mathrm{SO}_{4}$ mobile phase at a flow rate of $1 \mathrm{ml} \mathrm{min}^{-1}$. $A_{210}$ was detected. Retention times of products were compared to those of known standard compounds, including acetate, propionate and butyrate. Compound quantification was based on absorbances of known quantities of authentic compounds. Fermentation products were determined during early and late exponential phase, again during early stationary phase, and finally late in stationary phase.

Dehalogenation assays. Dehalogenation was determined at timed intervals throughout growth by measuring dehalogenation products by HPLC. Samples $(1 \mathrm{ml})$ were taken and mixed with an equal volume of $100 \%$ acetonitrile. After centrifugation to remove precipitated proteins and polysaccharides, the samples were assayed for bromophenols using the Hewlett Packard 1100 series HPLC system with a $15 \mathrm{~cm}$ HP $\mathrm{C} 18$ reversed-phase column and using a methanol: $\mathrm{H}_{2} \mathrm{O}$ : acetic acid $(50: 49: 1)$ mobile phase at a flow rate of $1.5 \mathrm{ml} \mathrm{min}^{-1}$. Detection was by $A_{280}$. Retention times of dehalogenation products were compared to those of authentic standard compounds, including 2-bromophenol, 4-bromophenol, DBP, 2,6-dibromophenol and TBP. Compound quantification was based on absorbances of known quantities of authentic compounds.

Determination of $\mathbf{G}+\mathbf{C}$ content ( $\mathbf{m o l} \%)$. DNA was isolated using a modification of the Marmur (1961) procedure, adding a cetyltrimethylammmonium bromide extraction step for removal of contaminating polysaccharides and proteins (Ausubel et al., 1987). The $\mathrm{G}+\mathrm{C}$ contents (mol\%) of each strain were determined after P1 nuclease digestion and HPLC separation of nucleosides (Mesbah et al., 1989; Whitman et al., 1986).

16S rDNA sequence determination and analysis. Genomic DNA was extracted and the gene encoding 16S rRNA (16S rDNA) was amplified as described previously (Rainey et al., 1996). Purified PCR products were directly sequenced using the Taq DyeDeoxy Terminator Cycle Sequencing kit (Applied Biosystems). Sequence reactions were electrophoresed using Applied Biosystems models 373A and 310 DNA sequencers. BLAST analysis was performed on the sequence data to determine the phylogenetic grouping to which the strains were most closely related (Altschul et al., 1990). The sequences determined in this study were aligned against those of Propionigenium modestum strain DSM $2376^{\mathrm{T}}$ (accession number X54275) and $P$. maris strain 10 succ ${ }^{\mathrm{T}}$ (accession number X84049) using the ae2 editor and sequence similarity values were calculated by pairwise sequence comparison (Maidak et al., 1994, 1999).

SDS-PAGE. Cultures of the three strains were grown with and without TBP to mid-exponential phase and harvested by centrifugation. Cell pellets were resuspended in $0 \cdot 1 \mathrm{M} \mathrm{NaOH}$ and incubated in a boiling water bath for $10 \mathrm{~min}$. Protein concentrations were determined by the Lowry assay (Lowry et al., 1951). Approximately $0.5 \mu \mathrm{g}$ sample was boiled in Laemmli sample buffer for $5 \mathrm{~min}$, then electrophoresed on a $12.5 \%$ SDS-polyacrylamide slab gel (Laemmli, 1970). Proteins were visualized by Coomassie brilliant blue staining.

\section{RESULTS AND DISCUSSION}

\section{Phylogenetic analyses}

16S rDNA sequences comprising $1441 \mathrm{nt}$ between positions 31 and 1493 (Escherichia coli numbering) were determined for strains DSL-1 and ML-1. Comparative analysis of the $16 \mathrm{~S}$ rDNA sequences with those sequences available for representatives of the major bacterial groups using BLAST analyses indicated that both strains were members of the low- $\mathrm{G}+\mathrm{C}$ Gram-positive subphylum. Alignment of the two sequences with those available for the members of the low-G + C Gram-positive subphylum and analysis of all nucleotide positions showed them to be most closely related to members of the genus Propionigenium. The $16 \mathrm{~S}$ rDNA sequence of strain DSL-1 had 99.7\% similarity to that of strain ML-1. The $16 \mathrm{~S}$ rDNA sequence similarity between strain DSL-1 and $P$. maris was $99.6 \%$ whereas that to $P$. modestum was $96.0 \%$. The 16S rDNA sequence of strain ML-1 had 99.9\% similarity to $P$. maris and $95.7 \%$ to $P$. modestum. The high degree of phylogenetic relatedness among the $P$. maris strains was also supported by SDS-PAGE protein profiling (Fig. 1), which showed very similar profiles for all three strains grown with or without TBP. These results are consistent with the designation of DSL-1 and ML-1 as strains of P. maris and do not support identifying them as new species within the genus Propionigenium.

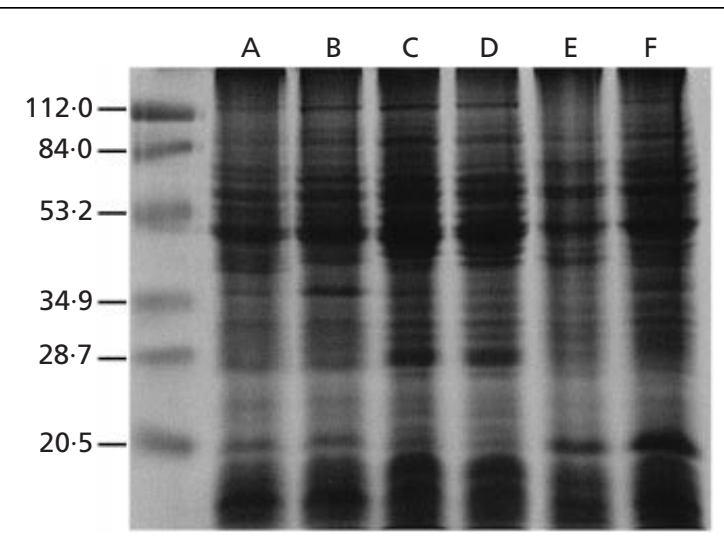

Fig. 1. Protein profiles of Propionigenium maris strains DSM $9537^{\top}, \mathrm{DSL}-1$ and ML-1 on a $12.5 \%$ SDS-polyacrylamide gel. Molecular mass standards (with $M_{\mathrm{r}}$ in thousands) are in the far left lane. Lanes: A, strain DSM $9537^{\top}$ grown without TBP; B, strain DSM $9537^{\top}$ grown with TBP; $C$, strain DSL-1 grown without TBP; $D$, strain DSL-1 grown with TBP; E, strain ML-1 grown without TBP; F, strain ML-1 grown with TBP. 
Table 1. Selected properties of Propionigenium maris strains

$P$. modestum is included for comparison.

\begin{tabular}{|c|c|c|c|c|}
\hline Property & $P$. maris DSL-1 & P. maris ML-1 & P. maris DSM $9537^{\mathrm{T} *}$ & P. modestum $\dagger$ \\
\hline Cell size $(\mu \mathrm{m}) \ddagger$ & $1.0 \times 0 \cdot 5$ & $2 \cdot 0 \times 0 \cdot 5$ & $2.5 \times 1 \cdot 0$ & $2.0 \times 0.5$ \\
\hline Inclusion & None & Present & None & None \\
\hline Carbon substrate & $\begin{array}{c}\text { Succinate, } \\
\text { pyruvate }\end{array}$ & Succinate, glucose & $\begin{array}{l}\text { Succinate, pyruvate, fumarate, } \\
\text { citrate, 3-hydroxybutyrate, } \\
\text { glucose, fructose, maltose }\end{array}$ & $\begin{array}{c}\text { Succinate, pyruvate, } \\
\text { fumarate, malate, } \\
\text { oxaloacetate, L-aspartate }\end{array}$ \\
\hline Fermentation products $\S$ & $\begin{array}{c}\text { Butyrate } \\
\text { (propionate) }\end{array}$ & $\begin{array}{c}\text { Propionate } \\
\text { (butyrate) }\end{array}$ & $\begin{array}{l}\text { Propionate (butyrate, acetate, } \\
\text { lactate, formate, ethanol) }\end{array}$ & Propionate (acetate) \\
\hline Optimum pH & $7 \cdot 5-7 \cdot 8$ & $7 \cdot 0$ & $6 \cdot 9-7 \cdot 7$ & $7 \cdot 1-7 \cdot 7$ \\
\hline $\begin{array}{l}\text { Optimum temperature } \\
\left({ }^{\circ} \mathrm{C}\right)\end{array}$ & 28 & 32 & $34-37$ & 33 \\
\hline $\mathrm{G}+\mathrm{C}(\mathrm{mol} \%)$ & 39 & 41 & 40 & $33 \cdot 9$ \\
\hline
\end{tabular}

* Data from reference Janssen \& Liesack (1995).

$\dagger$ Data from reference Schink \& Pfennig (1982).

$\ddagger$ Cell dimensions (length $\times$ width) for exponentially growing cells. All Propionigenium cells are rods.

$\S$ Products in parentheses for P. maris strains DSL-1 and ML-1 are minor products. Production of butyrate, acetate, lactate, formate and ethanol by $P$. maris DSM $9537^{\mathrm{T}}$ and acetate by $P$. modestum is dependent on the carbon source.

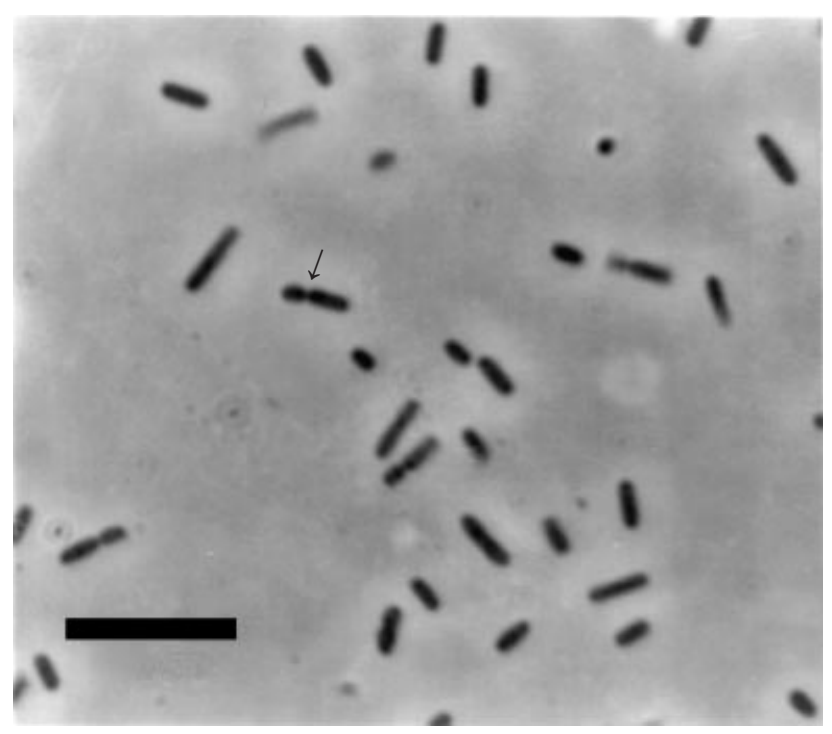

Fig. 2. Phase-contrast photomicrograph of Propionigenium maris strain DSL-1 during stationary phase. Note asymmetric cell division (arrow). Scale bar, $10 \mu \mathrm{m}$.

\section{Characterization of strains DSL-1 and ML-1}

Cell morphology. Cells of strain DSL-1 in exponential growth phase were short rods averaging $1 \mu \mathrm{m}$ in length and $0.5 \mu \mathrm{m}$ in diameter (Table 1). Stationary phase cells were shorter, some were almost spherical (Fig. 1). This strain displayed asymmetric cell division, with one daughter cell noticeably larger than the other during stationary phase (Fig. 2). Strain ML-1 was also rod-shaped and $0.5 \mu \mathrm{m}$ in diameter, but cell length during exponential growth was variable, ranging from
2 to $10 \mu \mathrm{m}$. Both strains became shorter and more uniform during stationary phase, with ML-1 length averaging $2 \mu \mathrm{m}$. Neither strain ML-1 nor the $P$. maris type strain displayed asymmetric cell division. Sporulation was not observed in either strain and is not a property of the genus Propionigenium (Schink \& Pfennig, 1982). Strain ML-1 contained dense inclusions that were most numerous in stationary phase cells (Fig. 3). No such inclusions were found in DSL-1 or in the P. maris type strain in any growth phase.

Gram stain reaction. The Gram stain reaction was negative but electron microscopy of osmiumtetraoxide-stained thin sections revealed a single darkstaining cell envelope layer (data not shown), consistent with a Gram-positive cell wall structure. No lipopolysaccharide (LPS), the characteristic compound of Gram type negative cell walls, was detected using the LPS-polymyxin B assay of Wiegel \& Quandt (1982). Other Propionigenium strains also stain Gramnegative (Schink \& Pfennig, 1982).

Growth properties. Neither strain could be grown in media that were not completely anoxic, indicating that both are obligate anaerobes. The $\mathrm{pH}$ range for growth of strain DSL-1 was $6 \cdot 5-8 \cdot 5$, with optimal growth at $\mathrm{pH} 7 \cdot 5-7 \cdot 8$. The $\mathrm{pH}$ range supporting growth of strain ML- 1 was $5 \cdot 5-7 \cdot 5$, and the optimum was $\mathrm{pH} 7 \cdot 0$. The lower $\mathrm{pH}$ optimum for strain ML-1 may reflect the stagnant conditions in $N$. lobatus burrows. $N$. lobatus burrow linings are compacted and heavily cemented with mucus (Steward et al., 1996). This cohesive structure somewhat impedes exchange between burrow water and sediment porewater (Aller, 1983). In addition, $N$. lobatus does not irrigate its burrow very energetically, as demonstrated by the very thin oxidized layer lining the burrow wall (Steward et al., 


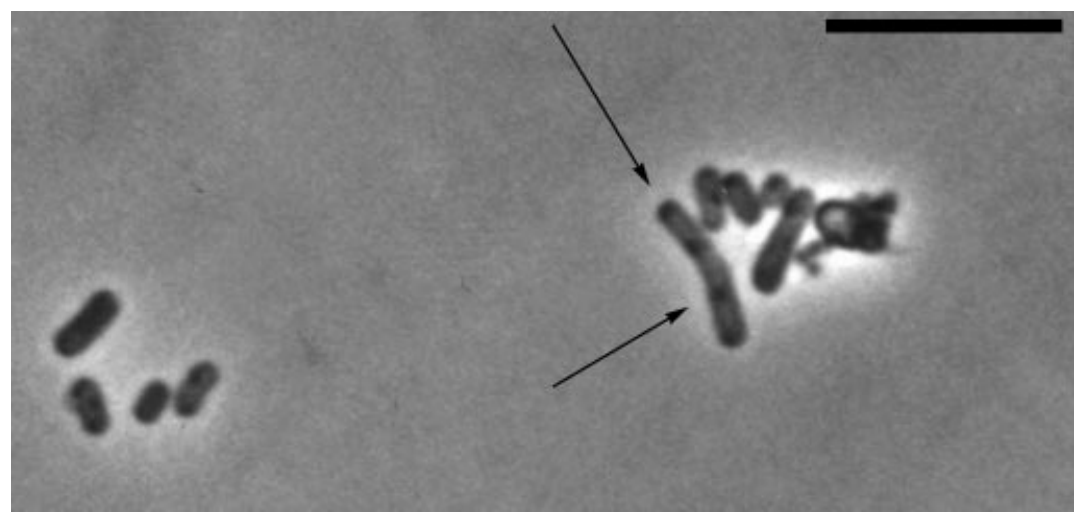

Fig. 3. Phase-contrast photomicrograph of Propionigenium maris strain $\mathrm{ML}-1$ during stationary phase. Note inclusions (arrows). Scale bar, $10 \mu \mathrm{m}$.

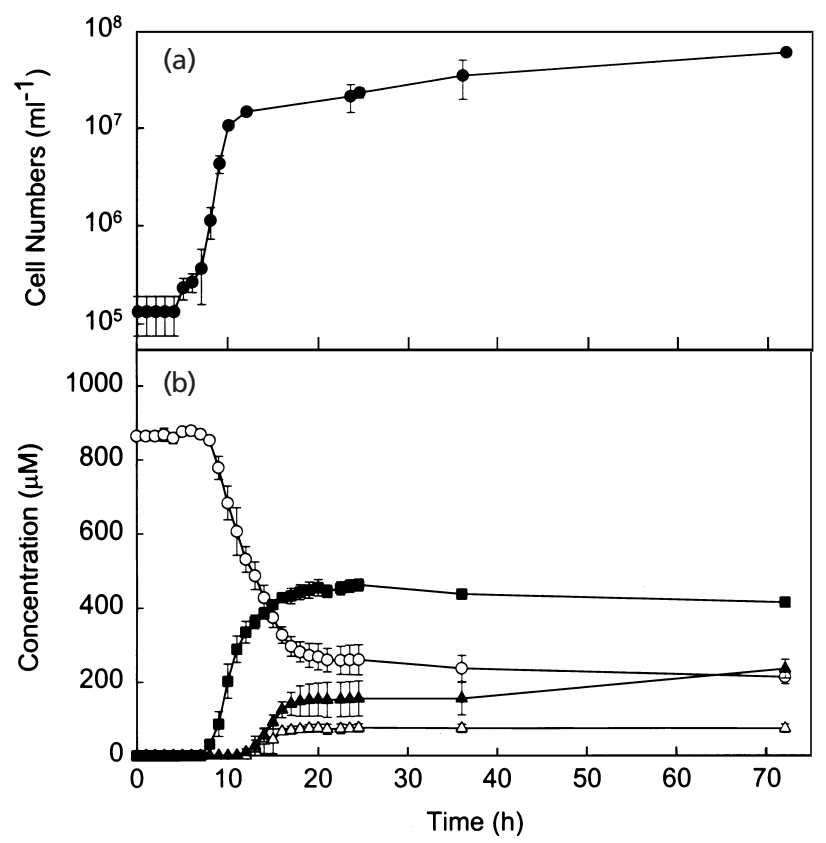

Fig. 4. (a) Growth of Propionigenium maris strain ML-1. (b) Debromination of TBP by Propionigenium maris strain $\mathrm{ML}-1$ : (O) TBP; ( $\mathbf{\square}) \mathrm{DBP} ;(\triangle)$ 4-bromophenol; ( $\boldsymbol{\Delta}$ ) 2-bromophenol. Values are means of three cultures incubated in parallel. Error bars represent one standard deviation. For symbols with no error bars, error bars are smaller than the symbols.

1996). Burrow stagnation permits accumulation of volatile fatty acids (chiefly propionate, lactate and acetate) produced by the worm under conditions of anaerobiosis (Schöttler et al., 1983; Surholt, 1977) and consequently, substantial decreases in burrow water $\mathrm{pH}$ (Scott, 1976). In contrast, the burrow linings of the hemichordate Balanoglossus aurantiacus, the source of DSL-1, are not very cohesive (Steward et al., 1996) and have little effect on burrow water exchange. This animal moves very actively during feeding and burrow construction, forcing substantial exchange among burrow water, sediment porewater and overlying seawater. The result of this exchange should be burrow water $\mathrm{pH}$ values that are substantially higher than those of $N$. lobatus burrow water and this is consistent with the higher $\mathrm{pH}$ optima of DSL-1. The temperature range for growth of strain DSL- 1 was $10-35^{\circ} \mathrm{C}$ and the optimum temperature was $30^{\circ} \mathrm{C}$. The optimum temperature for growth of strain ML-1 was similar, $32^{\circ} \mathrm{C}$. The shortest doubling times observed for strains DSL-1 and ML-1 at optimum $\mathrm{pH}$ and growth temperature were $0 \cdot 30-0.32 \mathrm{~h}$. Strain DSL-1 grew well within an $\mathrm{NaCl}$ concentration range of $1-5 \%$ with optimal growth at $2-3 \% \mathrm{NaCl}$ and no growth at 0 or $6 \%$. Strain ML-1 grew well from $1-4 \% \mathrm{NaCl}$ with optimal growth at $3 \%$ and no growth at 0 or $5 \%$. These results were consistent with the salinities observed in the euhaline saltmarsh environment from which these strains were isolated. The only defined carbon sources that were utilized in the presence of $0.05 \%$ yeast extract were pyruvate and succinate for strain DSL-1 and glucose and succinate for strain ML1. The growth rate of strain DSL-1 was increased over that in the basal medium by addition of succinate or pyruvate at concentrations up to $20 \mathrm{mM}$, but not above, whereas the growth rate of strain ML-1 was increased by succinate at concentrations up to $40 \mathrm{mM}$. Substrates that did not measurably increase the growth rate of either strain in the presence of $0.05 \%$ yeast extract included acetate, benzoate, citrate, crotonate, ethanol, fumarate, lactate, malate, oxalate and propionate. In addition, strain DSL-1 did not utilize glucose and ML-1 did not utilize pyruvate. Strain DSL-1 growing on either pyruvate or succinate showed exponential decline in cell numbers in stationary phase. In the absence of these supplemental carbon sources the decline in stationary phase cell numbers was less marked. A similar effect was observed for glucosegrown cultures of strain ML-1, which goes into exponential decline after stationary phase. These stationary phase cultures could not always be successfully subcultured. Strain ML-1 cultures grown with succinate could be successfully subcultured after as long as 4 months if they were kept at room temperature. No appreciable change in growth rate or yield of either strain resulted from addition of nitrate, fumarate or thiosulfate as potential terminal electron acceptors. The predominant fermentation product of strain DSL-1 at all growth stages was butyrate. Small amounts of propionate were also observed. In the absence of enzymology data the pathway used for 
butyrate production from succinate could not be determined. Strain ML-1 consistently produced propionate as its predominant fermentation product. Small amounts of butyrate were also observed. Similar to strain ML-1, the P. maris type strain (DSM 9537 $)$ utilizes succinate and glucose (as well as several other substrates), requires yeast extract and consistently produces propionate as its predominant fermentation product (Janssen \& Liesack, 1995).

Debromination. TBP was rapidly debrominated by both strains (Steward et al., 1995; Fig. 3). Other tribromophenol isomers were not tested. DBP was also debrominated by both strains. DSL-1 produced primarily 2-bromophenol as the terminal debromination product from both TBP and DBP; ML-1 produced a mixture of 2- and 4-bromophenol. The basis for the discrepancy between the previous report of 4-bromophenol production by strain DSL-1 (Steward et al., 1995) and the current observation of 2-bromophenol is not completely clear, but may be due to a change in the culture between the initial determinations and the present work. Neither strain could utilize 2- or 4bromophenol as carbon substrates. 3-Bromophenol was not tested. Neither strain dechlorinated chlorophenols. A newly isolated Desulfovibrio strain that debrominated bromophenols also did not dechlorinate chlorophenols (Boyle et al., 1999).

Bromophenols supplied at millimolar concentrations did not affect yield or doubling time of strain DSL-1 or ML-1. The absence of growth stimulation or change in growth yields indicates that debromination by these strains does not lead to energy production. This result is in contrast to a newly isolated Desulfovibrio strain, which can use bromophenols as terminal electron acceptors (Boyle et al., 1999). P. maris, the closest related organism to the two novel isolates based on $16 \mathrm{~S}$ rDNA sequence analysis, was also tested for dehalogenation activity. Growth of unadapted P. maris type strain DSM $9537^{\mathrm{T}}$ was strongly inhibited by $1 \mathrm{mM}$ TBP. After adaptation through successive subculturing using media containing $100-500 \mu \mathrm{M}$ TBP, type strain DSM $9537^{\mathrm{T}}$ could be grown in the presence of up to $500 \mu \mathrm{M}$ TBP and trace amounts of the debromination terminal product, 2-bromophenol, were detected. No indication of growth stimulation or evidence that debromination is coupled to energy production were obtained for any $P$. maris strains. Propionigenium species are regarded as purely fermentative anaerobes (Schink \& Pfennig, 1982; Janssen $\&$ Liesack, 1995). No increases in cell yields by $P$. modestum (Schink \& Pfennig, 1982) or any strain of $P$. maris in response to added nitrate, fumarate or thiosulfate have been observed. This indicates that no energy yielding electron transport phosphorylation system is functioning in these species.

$\mathbf{G}+\mathbf{C}$ content. The $\mathrm{G}+\mathrm{C}$ content of genomic DNA from DSL-1 is $39 \pm 0.3 \mathrm{~mol} \%$ (SD, $n=6$ ), $41 \pm 0 \cdot 1 \mathrm{~mol} \%$ (SD, $n=4$ ) for ML-1 DNA. These values are in good agreement with $\mathrm{G}+\mathrm{C}$ contents of other Propionigenium strains (Table 1).
In conclusion, the high $16 \mathrm{~S}$ rDNA sequence similarity found between strains DSL-1 and ML-1 and the two described species of the genus Propionigenium clearly indicate their membership in the genus Propionigenium. Based on several similarities to the $P$. maris type strain and phylogenetic analysis, the new isolates can be placed as novel strains in the species Propionigenium maris. The new strains have a high degree of $16 \mathrm{~S}$ rDNA sequence similarity to that of the $P$. maris type strain (99.6-99.9\%), but differ from the latter organism in several physiological features including cell size, substrate preferences, temperature and $\mathrm{pH}$ optima and, most importantly, ability to rapidly debrominate TBP. The infaunal burrow, a dynamic microenvironment that supports high bacterial biomass and activities, may promote rapid evolution of these Propionigenium strains, resulting in substantial physiological variability without concurrent changes in $16 \mathrm{~S}$ rDNA sequence. Our identification of these isolates as strains of $P$. maris is conservative and based on the high degree of $16 \mathrm{~S}$ rDNA sequence homology and the strong similarity of protein profiles among the new strains and the $P$. maris type strain.

The new $P$. maris strains have been isolated from infaunal burrows differing in key microenvironmental features. Such burrows can differ very substantially in size, shape and placement in the sediments, the texture and organic matter content of sediment in the burrow linings, and the porosity of the surrounding sediments (which affects solute transport rates) (see Steward et al., 1996 for further discussion). In addition, the behaviours of the host invertebrates can also differ substantially. Given this range of structures and microbiologically significant activities of the host animals, it is probable that many distinct strains of $P$. maris, and likely new Propionigenium species, occur in marine infaunal burrows.

\section{Emendation}

The species description for P. maris (Janssen \& Liesack, 1995) is emended for the property of reductive dehalogenation of bromophenols found in the linings of some marine infaunal burrows. In contrast to strains isolated from the burrows, which are regarded as a special habitat for some $P$. maris strains, the type strain DSM $9537^{\mathrm{T}}$ exhibits only minor debromination activity and only after prolonged adaptation. Furthermore, some strains may not utilize sugars and butyrate can be the major fermentation product from pyruvate and succinate, although the type strain forms propionate as the major product from glucose and succinate. Depending on the isolate, the cell size varies between 0.5 and $1 \mu \mathrm{m}$ in diameter and 1 and $10 \mu \mathrm{m}$ in length.

\section{ACKNOWLEDGEMENTS}

We are grateful to W. B. Whitman for help with determination of the $\mathrm{G}+\mathrm{C}$ contents of DSL-1 and ML-1. This research was supported by the Office of Naval Research, grant number N00014-96-0403 to C. R. L. 


\section{REFERENCES}

Abrahamsson, K. \& Klick, S. (1991). Degradation of halogenated phenols in anoxic natural marine sediments. Mar Pollut Bull 22, 227-233.

Allard, A.-S., Hynning, P.-A., Lindgren, C., Remberger, M. \& Neilson, A. H. (1991). Dechlorination of chlorocatechols by stable enrichment cultures of anaerobic bacteria. Appl Environ Microbiol 57, 77-84.

Aller, R. C. (1983). The importance of the diffusive permeability of animal burrow linings in determining marine sediment chemistry. J Mar Res 41, 299-322.

Altschul, S. F., Gish, W., Miller, W., Myers, E. W. \& Lipman, D. J. (1990). Basic local alignment search tool. J Mol Biol 215, 403-410.

Ausubel, F. M., Brent, R., Kingston, R. E., Moore, D. D., Seidman, J. G., Smith, J. A. \& Struhl, K. (1987). Current Protocols in Molecular Biology. New York, NY: Wiley.

Boothe, D. D. H., Rogers, J. E. \& Wiegel, J. (1997). Reductive dechlorination of chlorophenols in slurries of low-organiccarbon marine sediments and subsurface soils. Appl Microbiol Biotechnol 47, 742-748.

Boyle, A. W., Phelps, C. D. \& Young, L. Y. (1999). Isolation from estuarine sediments of a Desulfovibrio strain which can grow on lactate coupled to the reductive dehalogenation of 2,4,6tribromophenol. Appl Environ Microbiol 65, 1133-1140.

Chen, Y. P., Lincoln, D. E., Woodin, S. A. \& Lovell, C. R. (1991). Purification and properties of a unique flavin-containing chloroperoxidase from the capitellid polychaete Notomastus lobatus. J Biol Chem 266, 23909-23915.

El Fantroussi, S., Naveau, H. \& Agathos, S. N. (1998). Anaerobic dechlorinating bacteria. Biotechnol Prog 14, 167-188.

Fetzner, S. \& Lingens, F. (1994). Bacterial dehalogenases: biochemistry, genetics, and biotechnological applications. Microbiol Rev 58, 641-685.

Fielman, K. T. \& Targett, N. M. (1995). Variation of 2,3,4tribromopyrrole and its sodium sulfamate salt in the hemichordate Saccoglossus kowalevskii. Mar Ecol Prog Ser 116, 125-136.

Fielman, K. T., Woodin, S. A., Walla, M. D. \& Lincoln, D. E. (1999). Widespread occurrence of natural halogenated organics among temperate marine infauna. Mar Ecol Prog Ser 181, 1-12.

Genthner, B. R. S., Price, W. A., II \& Pritchard, P. H. (1989). Anaerobic degradation of chloroaromatic compounds in aquatic sediments under a variety of enrichment conditions. Appl Environ Microbiol 55, 1466-1471.

Häggblom, M. (1992). Microbial breakdown of halogenated aromatic pesticides and related compounds. FEMS Microbiol Rev 103, 29-72.

Häggblom, M. M. \& Young, L. Y. (1990). Chlorophenol degradation coupled to sulfate reduction. Appl Environ Microbiol 56, 3255-3260.

Häggblom, M. M. \& Young, L. Y. (1995). Anaerobic degradation of halogenated phenols by sulfate-reducing consortia. Appl Environ Microbiol 61, 1546-1550.

Hale, D. D., Reineke, W. \& Wiegel, J. (1994). Chlorophenol degradation. In Biological Degradation and Bioremediation Technologies of Toxic Chemicals, pp. 74-91. Edited by G. R. Chaudry. Portland, OR: Timber Press.

Holliger, C., Wohlfarth, G. \& Diekert, G. (1999). Reductive dechlorination in the energy metabolism of anaerobic bacteria. FEMS Microbiol Rev 22, 383-398.
Janssen, P. H. \& Liesack, W. (1995). Succinate decarboxylation by Propionigenium maris sp. nov., a new anaerobic bacterium from an estuarine sediment. Arch Microbiol 164, 29-35.

Janssen, D. B., Pries, F. \& van der Ploeg, J. R. (1994). Genetics and biochemistry of dehalogenating enzymes. Annu Rev Microbiol 48, 163-191.

King, G. M. (1986). Inhibition of microbial activity in marine sediments by a bromophenol from a hemichordate. Nature 323, 257-259.

King, G. M. (1988). Dehalogenation in marine sediments containing natural sources of halophenols. Appl Environ Microbiol 54, 3079-3085.

Laemmli, U. K. (1970). Cleavage of structural proteins during the assembly of the head of bacteriophage T4. Nature 227, 680-685.

Löffler, F. E., Sanford, R. A. \& Tiedje, J. M. (1996). Initial characterization of a reductive dehalogenase from Desulfitobacterium chlororespirans Co23. Appl Environ Microbiol 62, 3809-3813.

Lovell, C. R., Steward, C. C. \& Phillips, T. (1999). Activity of marine sediment bacterial communities exposed to 4-bromophenol, a polychaete secondary metabolite. Mar Ecol Prog Ser 179, 241-246.

Lowry, O. H., Rosebrough, N. J., Farr, A. L. \& Randall, R. J. (1951). Protein measurement with the Folin phenol reagent. $J$ Biol Chem 193, 265-275.

Maidak, B. L., Larsen, N., McCaughey, M. J., Overbeek, R., Olsen, G. J., Fogel, K., Blandy, J. \& Woese, C. R. (1994). The Ribosomal Database Project. Nucleic Acids Res 22, 3485-3487.

Maidak, B. L., Cole, J. R., Parker, C. T. \& 11 other authors (1999). A new version of the RDP (Ribosomal Database Project). Nucleic Acids Res 27, 171-173.

Marmur, J. (1961). A procedure for the isolation of deoxyribonucleic acid from micro-organisms. J Mol Biol 3, 208-218.

Mesbah, M., Premachandran, U. \& Whitman, W. B. (1989). Precise measurement of the $\mathrm{G}+\mathrm{C}$ content of deoxyribonucleic acid by high-performance liquid chromatography. Int J Syst Bacteriol 39, 159-167.

Mohn, W. W. \& Tiedje, J. M. (1992). Microbial reductive dehalogenation. Microbiol Rev 56, 482-507.

Monserrate, E. \& Häggblom, M. M. (1997). Dehalogenation and biodegradation of brominated phenols and benzoic acids under iron-reducing, sulfidogenic, and methanogenic conditions. Appl Environ Microbiol 63, 3911-3915.

Neilson, A. H. (1990). The biodegradation of halogenated organic compounds. J Appl Bacteriol 69, 445-470.

Ni, S., Fredrickson, J. K. \& Xun, L. (1995). Purification and characterization of a novel 3-chlorobenzoate-reductive dehalogenase from the cytoplasmic membrane of Desulfomonile tiedjei DCB-1. J Bacteriol 177, 5135-5139.

Phillips, T. M. \& Lovell, C. R. (1999). Distributions of total and active bacteria in biofilms lining tubes of the onuphid polychaete Diopatra cuprea. Mar Ecol Prog Ser 183, 169-178.

Rainey, F. A., Ward-Rainey, N., Kroppenstedt, R. M. \& Stackebrandt, E. (1996). The genus Nocardiopsis represents a phylogenetically coherent taxon and a distinct actinomycete lineage: proposal of Nocardiopsaceae fam. nov. Int J Syst Bacteriol 46, 1088-1092.

Remberger, M., Allard, A.-S. \& Neilson, A. H. (1986). Biotransformations of chloroguaiacols, chlorocatechols, and chloroveratroles in sediments. Appl Environ Microbiol 51, 552-558.

Schink, B. \& Pfennig, N. (1982). Propionigenium modestum gen. 
nov., sp. nov., a new strictly anaerobic, nonsporing bacterium growing on succinate. Arch Microbiol 133, 209-216.

Schöttler, U., Wienhausen, G. \& Zebe, E. (1983). The mode of energy production in the lugworm Arenicola marina at different oxygen concentrations. J Comp Physiol 149, 547-555.

Scott, D. M. (1976). Circadian rhythm of anaerobiosis in a polychaete annelid. Nature 262, 811-813.

Steward, C. C. \& Lovell, C. R. (1997). Respiration and assimilation of 4-bromophenol by estuarine sediment bacteria. Microb Ecol 33, 198-205.

Steward, C. C., Pinckney, J., Piceno, Y. \& Lovell, C. R. (1992). Bacterial numbers and activity, microalgal biomass and productivity, and meiofaunal distribution in sediments naturally contaminated with biogenic bromophenols. Mar Ecol Prog Ser 90, 61-71.

Steward, C. C., Dixon, T. C., Chen, Y. P. \& Lovell, C. R. (1995). Enrichment and isolation of a reductively debrominating bacterium from the burrow of a bromometabolite-producing marine hemichordate. Can J Microbiol 41, 637-642.

Steward, C. C., Nold, S. C., Ringelberg, D. B., White, D. C. \& Lovell, C. R. (1996). Microbial biomass and community structures in the burrows of bromophenol producing and non- producing marine worms and surrounding sediments. Mar Ecol Prog Ser 133, 149-165.

Surholt, B. (1977). Production of volatile fatty acids in the anaerobic carbohydrate metabolism in the lugworm Arenicola marina L. Comp Biochem Physiol 58B, 147-150.

Tschech, A. \& Pfennig, N. (1984). Growth yield and increase linked to caffeate reduction in Acetobacterium woodii. Arch Microbiol 137, 163-167.

Whitman, W. B., Sohn, S., Caras, D. S. \& Premachandran, U. (1986). Isolation and characterization of 22 mesophilic methanococci. Syst Appl Microbiol 7, 235-240.

Wiegel, J. \& Quandt, L. (1982). Determination of the Gram type using the reaction between polymyxin B and lipopolysaccharides of the outer cell wall of whole bacteria. J Gen Microbiol 128, 2261-2270.

Woodin, S. A., Walla, M. D. \& Lincoln, D. E. (1987). Occurrence of brominated compounds in soft-bottom benthic organisms. $J$ Exp Mar Biol Ecol 107, 209-217.

Yoon, K. S., Chen, Y. P., Lovell, C. R., Lincoln, D. E., Knapp, L. W. \& Woodin, S. A. (1994). Localization of the chloroperoxidase of the capitellid polychaete Notomastus lobatus. Biol Bull 187, 215-222. 